\title{
A CONTRIBUTION TO THE STUDY OF ACUTE SCHISTOSOMIASIS (AN EXPERIMENTAL TRIAL)
}

\author{
ZILTON A. ANDRADE \& THEOMIRA MAUADIE DE AZEVEDO \\ Centro de Pesquisas Gonçalo Moniz-FIOCRUZ - Rua Valdemar Falcão, 121, Brotas, 41945 Salvador, BA, \\ Brasil
}

In an attempt to establish an experimental model of acute schistosomiasis, sequential histological changes were investigated in the skin, lung, liver and spleen of mice infected with 30 or 100 cercariae of Schistosoma mansoni according to four sets of experiments: single infection, repeated infections, unisexual infection and infection in mice born from infected mothers. Animals were killed every other day from exposure up to 50 days after infection. Only mild, isolated, focal inflammatory changes were found before the appearance of mature eggs in the liver, even when repeated infections were made. Severe changes of reactive hepatitis and splenitis appeared suddenly when the first mature eggs were deposited, around the 37th to 42nd day after infection. The mature eggs induced lytic and coagulative necrosis of hepatocytes around them which was soon followed by dense infiltration of eosinophils. So, mature egg-induced lesions appeared as the major factors in the pathogenesis of acute schistosomiasis in mice. Mice bor from infected mothers were apparently able to rapidly modulate the egg-lesions, forming early fibrotic granulomas.

The murine model of acute schistosomiasis appeared adequate for the study of pathology and pathogenesis of acute schistosomiasis.

Key words: acute schistosomiasis - pathogenesis - experimental schistosomiasis

Acute (toxemic) schistosomiasis is a well characterized clinical entity. Some days after exposition to contaminated water the patients complain of lassitude, chills, fever, generalized muscular pain and artralgia. There also occur exanthemas, cough, mild hepatosplenomegaly and blood eosinophilia (Diaz-Rivera et al., 1956; Ferreira et al., 1966). It has been claimed that manifestations start during larval migration and are exacerbated following oviposition (Bogliolo \& Neves, 1965). Girges (1934) referred to acute schistosomiasis as presenting a first, pre-postural stage and a second or post-postural stage.

Acute schistosomiasis usually is observed in visitors to endemic areas, not in its indigenous populations. It seems to be related to a primary heavy infection, but occasionally cases have been reported in patients with mild to moderate infections (Hiatt et al., 1979) or in those already infected (Katz \& Bittencourt, 1965).

Pathogenesis has not been established, although the role of hypersensitivity to schistosomal antigens is generally admitted. The condition has been compared to serum sickness and to immediate-hypersensitivity diseases (Bogliolo \& Neves, 1965; Hiatt et al., 1979).

Although the acute changes in murine schistosomiasis have been exhaustively studied by many investigators, the experimental approach

Supported by FINEP (Grant No $2541 / 85$ )

Received Scptember 26, 1986.

Accepted December 4, 1986. to the study of acute schistosomiasis has not been attempted, probably because no one host can exhibit the complete and florid clinical picture such as that presented by man.

However, by following the sequential pathologic changes from cercarial penetration up to the period of oviposition in a susceptible experimental host, one could consider the moment of the abrupt onset of severe lesions in the liver and spleen as the counterpart of acute schistosomiasis of man.

By adopting this working hypothesis, an attempt was made to investigate the course of experimental schistosomiasis in the mouse soon after cercarial exposure up to the moment of oviposition, in order to inquire into: a) the type and the significance of pre-postural changes; $b$ ) the major factors related to the onset of acute changes since the exposure to oviposition and c) the morphology of the very early periovular lesions in the liver and their repercussions on the spleen.

\section{MATERIAL AND METHODS}

Four sets of experiments were performed in outbred albino Swiss mice of both sexes, weighing 18-20 grams, which were submitted to infection by the percutaneous route with recently shed cercariae from a local strain (Feira de Santana) of Schistosoma mansoni (Andrade \& Sadigursky, 1985). The cercariae were obtained from laboratory raised and infected Biomphalaria glabrata. Every time an infection was per- 
formed a total of 30 cercariae per mouse was utilized, except for the unisexual infections, which were performed with approximately 100 cercariae per mouse.

\section{Experiments:}

1. Single exposure. Mice subjected to a single $S$. mansoni infection were killed every other day from the second up to the 50th day following exposure. This experiment was intended to investigate the changes occurring during the pre-postural phase of the infection up to the moment when oviposition started.

2. Mice subjected to multiple infections. Every week the same group of mice was submitted to infection with $S$. mansoni cercariae. Every week, starting from the 9th day after the first infection and going on to the 40th day, two mice were killed and submitted to histologic examination. The refore, the first two mice killed were on the 9th day from the first infection and the 2nd from the second infection, while the last ones were on the 40th day from the first infection, the 32nd from the second, the 26th from the third, the 19th from the fourth, the 12th from the fifth and the 5th day from the sixth exposure.

3. Unisexual $S$. mansoni infection. Laboratory raised snails were submitted to infection with 1-5 miracidia, and the cercariae eliminated later on from each snail were used to infect mice. The animals were killed on day $40,45,60$ and 68 after exposure to cercariae. This experiment was performed to check whether the changes seen in the liver and spleen in the previous two groups after the 40th day of infection were really related to oviposition only.

4. Mice born from egg-positive $S$. mansoni infected mothers were, when adults, subjected to a single exposure of approximately 100 cercariae of $S$. mansoni. Two of them were killed every other day from the 2nd up to the 50 th day after infection.

Immunofluorescence test: Sera from all the animals of the first experiment (single exposure) were taken at the time of sacrifice. They were utilized for the detection of anti-schistosome antibodies by immunofluorescence. Sera were diluted 1:10 and placed over both cryostat and Bouin fixed paraffin embedded sections of mouse liver containing adult worms and eggs of $S$. mansoni A fluoresceinated anti-mouse globulin (IgG and IgM) was used at dilution of 1:40 for antibody detection, and the sections were examined under a Zeiss microscope equipped with epi-fluorescence.
Histological examination: Fragments of skin (infection site), lungs, liver and spleen were placed in Bouin's fixative and embedded in paraffin. The 5 micron thick sections were stained with hematoxylin and eosin.

\section{RESULTS}

Schistosomula were detected occasionally in the skin after the 2nd day of infection and in the lung from the 5 th to the 7 th days. No reaction was observed around these larvae in the host tissues at any time of the present experiments.

First experiment: Single infection. The presence of isolated immature worms started to be detected in histological sections after the 16th day of infection. Well developped worms were seen on day 26 and they formed pairs by the 30th day. Immature eggs with its basophilic contents and wavy shells were seen within blood capillaries around the 37th day. By this time pigmentation of Kupfer cells became prominent. No significant inflammatory changes were observed in the liver and spleen until the time when the presence of mature schistosome eggs could be observed. Only an occasional microscopic area of focal fibrosis was detected in the liver of a mice 16 days after infection (Fig. 1). In the center of that area there were some eosinophils and mononuclear cells. Another similar area, this time represented by focal hepatic necrosis with accumulation of cellular debris and infiltration by polymorphonuclear neutrophils was seen in an animal infected 33 days previously (Fig. 2).

The first few mature eggs were seen in the liver of a mouse killed on the 37 th day of infection. They appeared more regularly from the 40 th day on. When the first mature eggs were noted in the liver there was a peculiar reaction around them. It consisted of a central clear zone with necrotic debris and several vacuolated cells, probably hepatocytes, presenting severe hydropic changes (Fig. 3). At the periphery of that area, and sometimes within it, there were many eosinophils and macrophages and a few lymphocytes. The presence of micro-vacuolated hepatocytes around the mature egg lesions was observed on the 40th and 42nd days only. The reafter the mature eggs appeared surrounded by a fibromacrophagic granuloma which appeared infiltrated by many polymorphonuclear eosinophils. These latter cells usually accumulated in a necrotic area around the egg forming a zone of purulent necrosis. Occasionally, the lesions around the mature egg on the 40th day were represented by an extensive area of coagulative necrosis of hepatocytes surrounded by a collar of eosinophils (Fig. 4) 

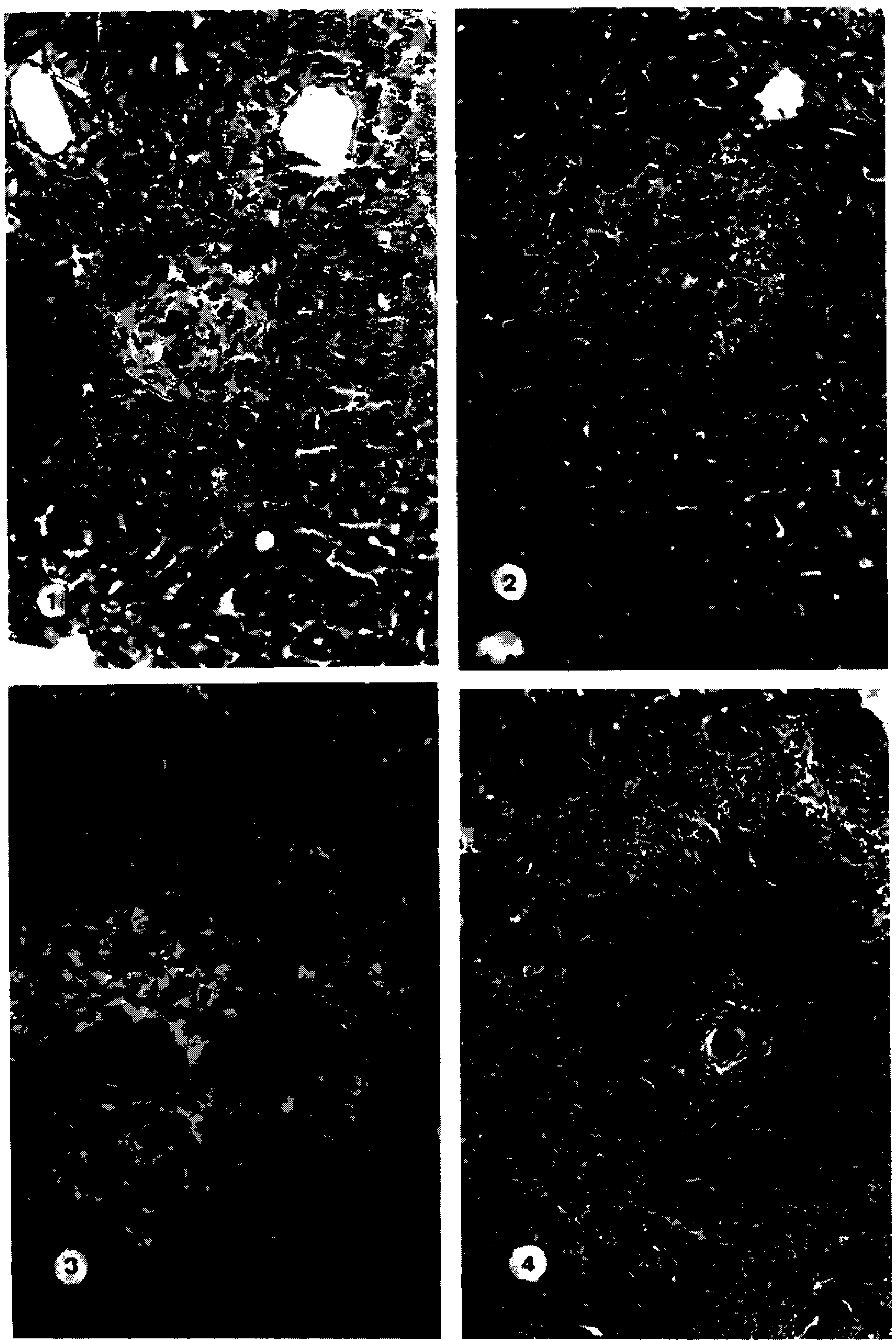

Fig. 1: An area of focal fibrosis containing few eosinophils and macrophages found in the liver of a mouse exposed to cercariac of $S$. mansoni 16 days previously. Hematoxylin and Eosin, X 100. Fig. 2: An area of focal hepatic necrosis, which is infiltrated by numerous eosinophils, observed in a mouse with a 33 day old $S$. mansoni infection. Hematoxylin and tosin, X 120. Fig. 3: An early periovular granuloma showing lytic necrosis of hepatocytes and scanty cosinophilic infiltration. Hepatocytes at the vicinity of the lesions present microvesicular cytoplasmic degeneration. Hematoxylin and Eosin, X 150. Irig. 4: Extensive area of hepatic coagulative necrosis around a $S$. mansoni egg in a mouse infected with $S$. mansoni 40 days ago. Around the necrotic area inflammatory cells, mostly polymorphonuclear eosinophils, are accumulated. Hematoxylin and Eosin, X 100. 

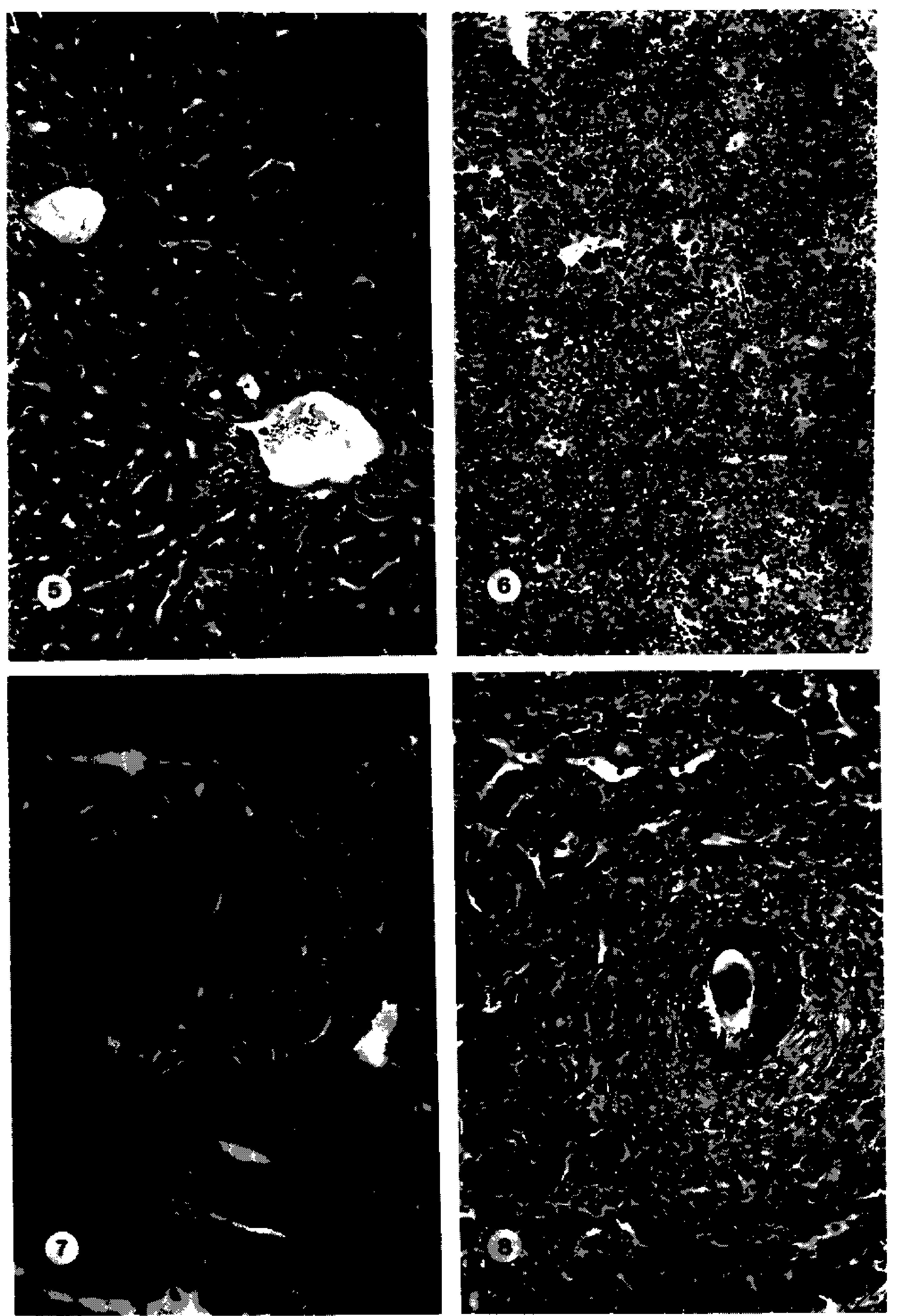

Fig. 5: Acute schistosomal hepatitis. Mononuclear cells and polymorphonuclear eosinophils appear infiltrating portal spaces and forming small foci within the parenchyma. Kupffer cells are prominent. Hematoxylin and eosin, $X$ 120. Fig. 6: Increased cellularity with many basophilic cells in the red pulp of the spleen in a mouse with early egg-induced lesions in the liver. Hematoxylin and Eosin, X 100. Fig. 7: Several near-mature $S$. mansoni adult male worms inside a portal vein branch with thrombosis, endo and peri-phlebitis. Unisexual infection. Hematoxylin and Eosin, X 100. Fig. 8: A well developed periovular granuloma showing central necrosis and fibrotic transformation detected in the liver of a mouse, born from infected mother, and infected 40 days ago. Hematoxylin and Eosin, X 150. 
The appearance of mature eggs and the reaction around them coincided with diffuse reactive hepathic changes. The Kupffer cells showed hypertrophy and hyperplasia as well as pigmentation. There were microscopic foci of inflammatory cells, especially eosinophils, within the sinusoids. A diffuse infiltration of eosinophils and macrophages was seen in the portal spaces and around central veins (Fig. 5). Isolated liver cell necrosis, sometimes forming hyaline bodies, was a frequent finding. Paired adult worms were found within the portal vein branches in the absence of endothelial reaction.

Although a few reactive changes could be noted in the spleen before the deposition of mature eggs in the liver, clear cut alterations were observed following egg maturation. By this time the spleen was observed to be grossly enlarged, two to three times its normal volume. Microscopically the white pulp was enlarged, with clear reactive germinal centers and some cells exhibiting mitosis. The splenic cords disclosed increased cellularity, with prominent and pigmented macrophages, many foci of myelopoiesis, focal proliferation of basophilic cells and moderate infiltration of eosinophils (Fig. 6). No schistosome eggs were detected in the sections of the splenic tissue examined.

2nd Experiment: Multiple infections. Results were essentially similar to those found in the previous experiment. The exception was that after the 30th day from the first infection, when the animals had been exposed to 5 infections, there appeared focal areas of ischemic necrosis in the liver, followed by infiltration of inflammatory cells, and accompanied by mild non-specific reactive changes in the liver as a whole. Mild to moderate reactive changes were noted in the spleen too. Both isolated and paired worms were seen within portal vein branches, but no eggs. Changes in liver and spleen progressively increased in the following days and were considerably aggravated by the time when focal necrotic-inflammatory changes formed around the mature eggs.

3rd Experiment: Unisexual infection. The animals were killed after the 40th day following infection and also on the 45th, 60th and 68th day. Only male worms were found in the sections examined. There was variable degree of pigmentation of the Kupffer cells. Focal ischemic necrosis of the liver parenchyma was frequently observed, as well as mild to moderate reactive changes (monuclear cell infiltration with a few eosinophils) in the portal spaces and around hepatic vein branches. The worms were sometimes numerous and their presence was associated with endo and periphlebitis, which were exaggerated when some worms died and disintegrated forming a nucleus for an intravascular fibrinous thrombus (Fig. 7).

The reactive changes in the spleen correlated well with those seen in the liver.

\section{4th. Experiment: Infection of animals born} form infected mothers. Findings did not differ from those observed in the first experiment. The most prominent changes appeared associated with the deposition of mature eggs in the liver. The peculiar clear zone of necrosis and hydropic degeneration was seen around the first mature eggs appearing from the 35 th to the 42 nd day after infection. However, it appeared that rapid fibrotic changes took place within some of the periovular granuloma in a clear contrast to the other groups. Even as early as the 40th day after infections, periovular granulomas, with evident fibroblastic proliferation and collagen deposition, were seen side by side with those showing predominant exsudative changes.

Serum antibodies: Antibodies were detected for the first time in the sera of mice with single infection on day 16 after exposure to cercariae of $S$. mansoni. They were found to bind exclusively to the intestinal lumen of adult worms. By the 23 rd day on all stages of $S$. mansoni present in the mouse liver appeared fluorescent, especially the cephalic glands of the miracidium and the intestinal lining and the tegument of adult worms.

\section{COMMENTS}

The assumption that the acute reactive changes seen in the liver and spleen of mice represent the experimental counterpart of acute (toxemic) schistosomiasis of man can be quite controversial and should not be taken too literally. However such assumption may be helpful when one attempts to identify the factors which may be related to the abrupt onset of generalized reactive changes during the early course of a primary schistosomal infection. In the murine model the larval migration during a primary infection did not evoke significative host changes, even when multiple infections were made before the first one had come to the stage of oviposition.

Studies in man have emphasized that the manifestations of acute schistosomiasis may appear during the larval migration period (DiazRivera et al., 1956; Ferreira et al., 1966; Neves et al., 1966). Hiatt et al. (1979) refer to incubation times of 11,13 and 15 days observed among their 26 patients examined in Puerto Rico. Bogliolo \& Neves (1965) examined hepatic biopsy material from three patients presenting incubation periods from 21 to 23 days. They observed acute hepatitis with focal necro- 
sis and dense infiltration of eosinophils and neutrophils and a few macrophages. They considered these changes as caused by a hyperergic reaction against dead schistosomula and/or immature worms. This same suggestion has been advanced by Dias-Rivera et al. (1956).

Apparently, the murine model is not appropriate for the study of the pre-postural stage of acute schistosomiasis in man. However, a certain degree of sensitization to schistosomal antigens does occur in pre-postural murine schistosomiasis. A proteoglycan antigen was shown to be present in the epithelial lining of the primordial esophagus and cecum of cercariae and schistosomula (Andrade \& Sadigursky, 1978) and was found in the circulation and lirine of heavily infected hamsters, 18 days after infection (Gold, et al., 1969). Antibodies binding specifically to the epithelial lining of the gut of adult schistosomes were detected in the sera of mice as early as 16 days after exposure during the present investigation. These antibodies, which are present mainly in the IgM fraction of the immunoglobulins (Andrade \& Sadigursky, 1978), have been considered as good markers of acute schistosomiasis in man (Nash et al., 1983). Helden et al. (1975) have observed that sera from patients with early infection contain antibodies that bind to the schistosome gut during immunofluorescence tests ("focal pattern") in contrast to sera taken during late infections which induce a "diffuse pattern".

In the present investigation some occasional changes did appear during the larval stage of the infection. A small focal area of fibrosis and inflammation was seen in the liver of a mouse 16 days after infection. Focal necrosis with eosinophilic infiltration appeared in another on day 33 following exposure. Also, a cluster of immature male worms were seen in one case, provoking severe thrombophlebitis of a portal branch. These lesions were apparently isolated and did not seem to cause significant generalized alterations. However, depending on their number, such lesions could assume clinical significance. lt is not known whether a patient presenting pre-postural symptomatology is afflicted with a particularly heavy infection. Histological findings in the liver suggest so (Bogliolo \& Neves, 1965).

Explosive changes in the liver and spleen appeared when the first mature eggs were found in the liver. It was interesting to see that the first mature eggs evoked a halo of lytic or coagulative necrosis of the hepatic parenchyma around them, which was soon followed by severe inflammatory changes. The picture was similar to that found in athymic mice infected with either S. mansoni (Byram \& Lichtenberg, 1977) or S. japonicum (Cheever et al., 1985), and illustrates the fact that periovular granuloma formation is a reaction aimed at sequestering antigens and protecting the host tissues (Lichtenberg, 1964). Probably, the sooner the host is able to modulate the immunological reaction around the mature eggs, the better he will be protected. Although the present investigation was not planned to investigate this point, the periovular granuloma seen in mice born from infected mothers underwent a rapid fibrotic change, suggesting a rapid immunological modulation.

It has been a common experience that people living in endemic areas usually do not present the syndrome of acute schistosomiasis. The explanation for that observation is obscure. There is a possibility of immunological alteration of the host during the prenatal ou neonatal period (Lewert \& Mandlowitz, 1969) when the host maybe in contact with antigens, antibodies and/or immunecomplexes from infected mothers. This subject needs further investigation, but the findings from the present study suggest that the mice born from infected mothers have an altered reactivity to the mature eggs of $S$. mansoni deposited within their livers during a primary infection.

\section{RF:SUMO}

Contribuição ao estudo da esquistossomose aguda (uma tentativa experimental) - Numa tentativa para se estabelecer um modelo experimental para o estudo da esquistossomose aguda. foram estudadas as alteraçōes presentes na pele. pulmões, fígado e baço de camundongos submetidos a infecção com 30 ou 100 cercarias do Schistosoma mansoni c divididos em quatro tipos de experimentos: infecção simples. infecçōes repetidas, infecção unissexuada e infecção em animais provenientes de mães infectadas. Os animais foram sacrificados em dias alternados a partir do momento da infecção até 50 dias depois. As lesōes encontradas na fase pré-postural foram discretas e poucas, mesmo quando os animais foram submetidos a infecçōes repetidas. As alterações mais súbitas e significativas de hepatite e esplenite reacionais surgiram quando os primeiros ovos maduros apareceram no fígado. As lesōes mais iniciais em torno de ovos maduros eram representadas por necrose lítica ou coagulativa, as quais se seguiam forte infiltraçāo de eosinófilos. Estas lesōes aparecem como os principais elementos na patogenia da esquistossomose aguda do camundongo.

Nos animais oriundos de mães infectadas as lesoes iniciais em torno de ovos maduros sofreram uma rápida transformação fibrosa, parecendo influenciadas por um diferente tipo de modulação imunológica. 
O modelo murino se revelou interessante para as investigaçōes sobre a patologia e patogenia da esquistossomose aguda.

Palavras-chave: esquistossomose aguda - patogenese esquistossomose experimental

\section{REFERENCES}

ANDRADE, Z.A. \& SADIGURSKY, M., 1978. Immunofluorescence studies of schistosome structures which share determinants with circulating schistosome antigens. Trans. R. Soc. Trop. Med. \& Hyg., $72: 316-318$.

ANDRADF, Z.A. \& SADIGURSKY, M., 1985. Um estudo comparativo das cepas Feira de Santana (Bahia) e Porto Rico do Schistosoma mansoni na infecção experimental do camundongo. Mem. Int. Oswaldo Cruz, $30: 37-40$.

BOGLIOLO, L. \& NFVFS, J., 1965. Ocorrência da hepatite na forma aguda ou toxemica da esquistos. somose mansoni, antes da maturação dos vermes e da postura dos ovos, com algumas considerações sobre a forma aguda ou toxemica da esquistossomose. Anais Fac. Med. Univer. Minas Gerais, 22 :47-74.

BYRAM, J.F. \& LICHTENBERG, F,, 1977. Altered schistosome granuloma formation in nude mice. Am. J. Trop. Med. Hyg., $26: 944-956$.

CHLIVFR, A.W.; BYRAM, J.E. \& LICHTENBERG, F.. 1985. Immunopathology of Schistosoma japonicum infection in athymic mice. Parasite Immunol., $7: 387-398$.

DIAZ-RIVIRA, R.S.; RAMOS-MORALFS, 1 ; ; KOP. PISCH, E.; GARCIA-PALMIERI, M.R.; CINTRONRIVERA, A. A.; MARCHAND, E.J.; GONZALES, O. \& TORREGROSSA M.V., 1956. Acute Manson's Schistosomiasis. Am. J. Med., 21 :918-943.

IERREIRA, H, OLIVIIRA, C.A.; BITTENCOURT, D.; KATZ, N.; CARNEIRO, L.F.C.; GRINBAUM,
E.; VELOSO, C.; DIAS, R.P.; ALVARENGA, R. J.; DIAS, C. B., 1966. A fase aguda da esquistossomose mansoni. Consideraçōes sobre 25 casos obser. vados em Belo Horizonte. J. Bras. Med., 11 :54-67.

GIRGES, R., 1934. Schistosomiasis (Bilharziosis). John Bale Sons \& Danielson Ltd, London, p. 136. GOLD, R.; ROSEN, F.S. \& WELLER, T.H., 1969. A specific circulating antigen in hamsters infected with Schistosoma mansoni. Detection of antigen in serum and urine and correlation between antigenic concentration and worm burden. Am. J. Trop. Med. Hyg., $18: 545-552$.

HELDEN, H.P.T.; TERPSTRA, W.J.; OKOT-KOBTER, B.M. \& EYAKUZE, V.M., 1975. Are there stage characteristic immunofluorescence patterns in schistosomiasis? Trans. R. Soc. Trop. Med. Hyg., 69 :309-311.

HIATT, R.A.; SOTOMAYOR, R.; SANCHEZ, G.; ZAMBRANA, M. \& KNIGHT, W.B., 1979. Factors in the pathogenesis of acute schistosomiasis manso. ni. J. Infect. Dis., $139: 659 \cdot 666$.

KATZ, N. \& BITTENCOURT, D., 1965. Sobre um caso de possível forma toxemica no decurso da forma hépato-esplénica da esquistossomose mansonica. Hospital, $67: 847-858$.

LEWLRT, R.M. \& MANDLOWITZ, S., 1969. Schistosomiasis: prenatal induction of tolerance to angigens. Nature, $224: 1029-1030$.

LICHTENBERG, F., 1964. Studies on granuloma formation. III. Antigen sequestration and destruction in the schistosome pseudotubercle. Am. J. Path., $45: 75-93$.

NASH, T.E.; GARCIA-COYCO, C.; RUIZ-TIBEN, E.; NAZARIO-LOPEZ, H. E.; VASQUEZ, G. Y TORRES-BORGFS, A., 1983. Differentiaticn of acute and chronic schistosomiasis by antibody responses to specific schistosome antigens. Am. J. Trop. Med. Hyg., $32: 776-784$.

NEVES, J.; MARTINS, L.L. \& TONELLI, E., 1966. Forma toxemica da esquistossomose mansônica: consideraçōes diagnósticas em torno de 50 casos identificados em Belo Horizonte. Hospital, 70 :143-163. 